\title{
Early Postnatal Development of Thyrotropin-Releasing Hormone (TRH) Expression, TRH Receptor Binding, and TRH Responses in Neurons of Rat Brainstem
}

\author{
Douglas A. Bayliss, ${ }^{1,2}$ Félix Viana, ${ }^{1}$ Robert K. Kanter, ${ }^{2}$ Caroline L. Szymeczek-Seay, ${ }^{2}$ Albert J. Berger, ${ }^{1}$ and \\ David E. Millhorn² \\ 1Department of Physiology and Biophysics, University of Washington School of Medicine, Seattle, Washington 98195 and \\ 2Department of Physiology, School of Medicine, University of North Carolina, Chapel Hill, North Carolina 27599
}

We investigated the postnatal development of the thyrotropin-releasing hormone ( $\mathrm{TRH}$ )-containing raphe system in the brainstem of neonatal rats. Postnatal changes in TRH expression in nucleus $(n$.$) raphe obscurus (R O b)$ and $n$. raphe pallidus (RPa) were evaluated by in situ hybridization using an ${ }^{35}$ S-labeled oligonucleotide probe complementary to TRH precursor mRNA. TRH mRNA expression was low at birth Ipostnatal day 0 (P0)], but was clearly evident by $P 7$ and increased from that time to reach sustained high levels from P14 to P28. Consistent with this postnatal increase in TRH expression, we found increases in the density of $\mathrm{TRH}$-immunoreactive (IR) fibers, which are derived from ROb and RPa, in the hypoglossal nucleus ( $\mathrm{XII}$ ). TRH-IR fibers in $\mathrm{nXII}$ were very sparse at PO, but increased markedly over the first 2 postnatal weeks. The change in TRH innervation of $\mathrm{nXII}$ was closely matched by concomitant increases in ${ }^{3} \mathrm{H}$ methyl-TRH binding in $\mathrm{nXII}$; specific TRH binding increased from very low levels at birth to high levels by P14. Finally, we recorded intracellularly the electrophysiological responses to TRH of hypoglossal motoneurons (HMs; $n=42$ ) of neonatal rats (P0-P21) in a brainstem slice preparation. The response of neonatal HMs to TRH, in contrast to adult HMs, was highly variable. In some neonatal HMs, even at PO, TRH caused a depolarization with a decrease in input conductance $\left(G_{N}\right)$ that was characteristic of the response of all adult HMs. However, in other neonatal HMs, TRH was either without effect or caused a slight depolarization with no apparent change in $G_{N}$ responses that were unlike those of adult HMs. A response was considered typical (i.e., "adultlike") if $G_{N}$ decreased to $<85 \%$ of control. The percentage of cells responding in a typical manner increased progressively from $25 \%$ at $P 0-P 2$ to $100 \%$ after $P 11$. In addition, we found that the density of TRH-sensitive current (normal-

Received Mar. 26, 1993; revised July 26, 1993; accepted Aug. 12, 1993.

We thank Luisa E. Klingler for expert technical assistance and gratefully acknowledge the contributions of Dr. William Satterthwaite, especially in the development of software for data analysis. We also thank Dr. Tamas Gorcs for supplying the TRH antisera. D.A.B. was supported by a Parker B. Francis Fellowship. C.L.S.-S. was supported in part by a fellowship from Glaxo Pharmaceuticals (Cilaxn, Research Triangle Park, NC). This work was supported by HL33831 and HD28948 (D.E.M.) and by HL49657 (A.J.B.).

Correspondence should be addressed to Douglas A. Bayliss, Department of Physiology and Biophysics, SJ-40, University of Washington School of Medicine, Seattle, WA 98195.

Copyright (C) 1994 Society for Neuroscience $0270-6474 / 94 / 140821-13 \$ 05.00 / 0$ ized to cell capacitance) increased with postnatal age in HMs that responded in a typical manner, suggesting that expression of the TRH-sensitive conductance is also developmentally regulated. Together, these data indicate that the TRH raphe neuronal system of the rat brainstem is not fully mature at the time of birth but develops over the first few postnatal weeks. This was true of levels of TRH mRNA in caudal raphe nuclei, density of TRH-IR fibers and ${ }^{3} \mathrm{H}$-methyl-TRH binding in $\mathrm{nXII}$, and also the manner and magnitude of electrophysiological responses of HMs to exogenously applied TRH.

IKey words: ontogeny, hypoglossal, motoneuron, raphe, electrophysiology, in situ hybridization, radioligand binding, immunohistochemistry]

During the course of early postnatal development many changes take place in the neuromuscular system, including elimination of polyneuronal innervation of muscle fibers (Brown et al., 1976) and differentiation of muscle fiber type (Navarette and Vrbová, 1983). As an additional part of this normal maturational process, intrinsic properties of motoneurons (e.g., membrane resistivity, rheobase, spike and afterhyperpolarization duration, etc.) change dramatically during the first 2 postnatal weeks (Fulton and Walton, 1986; Viana et al., in press). Developmental changes in neurotransmitter systems that modulate motoneuronal behavior or in mechanisms mediating effects of neurotransmitters on motoneurons may also contribute to overall maturation of the neuromuscular system. In this respect, it was recently reported that the density of serotonin (5-hydroxytryptamine, 5-HT)-immunoreactive (IR) fibers increases in the spinal cord ventral horn during the early postnatal period (Rajaofetra et al., 1989; Ziskind-Conhaim et al., 1993); those fibers are derived from raphe neurons of the caudal brainstem that are thought to modulate motor activity (reviewed in Jacobs and Azmitia, 1992). Interestingly, the increased 5-HT fiber density was correlated with increases in the depolarizing effects of 5-HT on spinal motoneurons, suggesting parallel development of the pre- and postsynaptic elements in the raphe-motoneuronal system (Ziskind-Conhaim et al., 1993).

In addition to 5-HT, brainstem raphe neurons [e.g., n. raphe obscurus ( $\mathrm{ROb}), \mathrm{n}$. raphe pallidus $(\mathrm{RPa})]$ synthesize a number of neuropeptides, including substance $P(S P)$ and thyrotropinreleasing hormone (TRH) (Johansson et al., 1981). Neuroanatomical and electrophysiological evidence suggests that TRH may subserve some of the modulatory effects of the raphe system 
on motor behaviors in adult rat. For example, TRH-containing fibers that emanate from the TRH-synthesizing neurons in $\mathrm{ROb}$ and RPa (Johansson et al., 1981; Lynn et al., 1991) are located near motoneurons (Hökfelt et al., 1975a,b; Johansson et al., 1981; Merchenthaler et al., 1988). In addition, TRH binding sites are found in motor nuclei (Manaker and Rizio, 1989; Sharif, 1989; Burt and Sharif, 1990) and motoneurons express mRNA encoding TRH receptor (Calzá et al., 1992). Furthermore, TRH is known to have direct excitatory effects on adult motoneurons (Rekling, 1990; Bayliss et al., 1992a) and may mediate a slow excitatory postsynaptic potential in spinal motoneurons (Takahashi, 1985).

Although the TRH neuronal system is reasonably well described in the adult rat, there is a paucity of information regarding its postnatal development. There is some evidence suggesting that the TRH system is not fully developed at the time of birth. For example, TRII is undetectable (Lamberton et al., 1984) or detected at low levels (Jeffcoate et al., 1983) in rat brainstem extracts at the time of hirth. Over the first few postnatal weeks TRH levels increase dramatically to near adult levels (Jeffcoate et al., 1983; Lamberton et al., 1984). Further, in a recent immunohistochemical study the TRH innervation of the ventral horn was found to increase substantially from the time of birth to reach adult levels by postnatal day 21 (P21; Poulat et al., 1992). In addition, in many areas of the CNS (e.g., hypothalamus, striatum, amygdala) the density of TRH binding sites increases during postnatal development (Blanchard and Barden, 1986). However, information regarding differences in expression of TRH receptors by neonatal and adult motoneurons has not been forthcoming. In this regard, although electrophysiological effects of TRH on neonatal motoneurons have been demonstrated (Takahashi, 1985; Nistri et al., 1990; Wang and Dun, 1990), the response to TRH is less consistently expressed in neonatal spinal motoneurons (52\% of cells; Wang and Dun, 1990) than in adult hypoglossal motoneurons (HMs) (100\% of cells; Rekling, 1990; Bayliss et al., 1992a). Although this might simply be due to differences between spinal and cranial motoneurons unrelated to development, it could also reflect a postnatal increase in TRH receptor expression.

Because of the potential important influence of caudal raphe neurons and TRH on motor behaviors, and in light of the scarcity of data regarding the postnatal maturation of the $\mathrm{TRH}$ neuronal system, we performed studies to determine the developmental time course of (1) expression of TRH mRNA in neurons of the caudal raphe nuclei, (2) arrival of TRH innervation at the hypoglossal motor nuclei (nXII), (3) appearance of TRH binding sites in nXII, and (4) onset of electrophysiological responses of HMs to TRH. We chose to study HMs because we previously demonstrated that all adult HMs respond to TRH. Furthermore, because HMs control tongue movement and contribute to the maintenance of upper airway patency (Remmers et al., 1978), early developmental changes in the behavior of these cells could have relevance to neonatal pathologies thought to involve airway obstruction (e.g., sudden infant death syndrome; Willinger, 1989).

We found that the TRH neuronal system and the motoneuronal responses to TRH are immature at the time of birth and develop over the first 2-3 postnatal weeks. Interestingly, increases in the levels of TRH mRNA in raphe neurons and in the number of TRH-containing fibers in $\mathrm{nXII}$ appear to parallel increases in the amount of TRH binding in $\mathrm{NXII}$ and the percentage of TRH-responsive HMs. This indicates a highly co- ordinated regulation of synthesis of the neuropeptide at its source and expression of the cognate receptor at the target.

Some of these data have been presented in preliminary form (Szymeczek et al., 1990; Millhorn et al., 1991; Bayliss et al., 1992b).

\section{Materials and Methods}

In situ hybridization-TRH $m R N A$. Sprague-Dawley rats of either sex were taken at postnatal day 0 (P0) (day of birth), P7, P14, P21, and $\mathrm{P} 28$, and either rapidly decapitated $(<\mathrm{P} 14)$ or anesthetized using ketamine and xylazine $(200 \mathrm{mg} / \mathrm{kg}$ and $14 \mathrm{mg} / \mathrm{kg}, \mathrm{i} . \mathrm{m}$.) and decapitated. Brains were removed quickly and the brainstem was blocked and frozen onto cryostat chucks over dry ice. Coronal sections $(10 \mu \mathrm{m})$ were cut on a microtome in a cryostat, thaw mounted onto twice-gelatin-coated slides, and stored at $-80^{\circ} \mathrm{C}$. Tissue sections from each age group were processed concurrently under identical conditions for each experiment $(n=6)$. Sections were processed for in situ hybridization essentially as described (Bayliss ct al., 1990; Scroogy ct al., 1991). Bricfly, slidc-mountcd sections were allowed to equilibrate at room temperature, fixed in $4 \%$ paraformaldehyde in $0.1 \mathrm{M}$ phosphate buffer (PB), rinsed extensively in $0.1 \mathrm{M}$ phosphate-buffered saline (PBS; once with $2 \mathrm{mg} / \mathrm{ml}$ glycine), and placed in $0.25 \%$ acetic anhydride in $0.1 \mathrm{M}$ triethanolamine $/ 0.9 \%$ saline $(\mathrm{pH} 8)$ before being transferred through a graded series of alcohols and chloroform. The sections were air dried before incubation for 18-24 hr at $37^{\circ} \mathrm{C}$ with $100 \mu \mathrm{l}$ of hybridization buffer [50\% formamide; $4 \times \mathrm{SSC}$ $(1 \times \mathrm{SSC}=0.15 \mathrm{M} \mathrm{NaCl}, 0.015 \mathrm{M}$ sodium citrate, $\mathrm{pH} 7.0) ; 10 \%$ dextran sulfate; $0.02 \%$ each of Ficoll, polyvinylpyrrolidone, and bovine serum albumin; $100 \mathrm{~mm}$ dithiothreitol, $500 \mu \mathrm{g} / \mathrm{ml}$ denatured salmon sperm DNA; and $250 \mu \mathrm{g} / \mathrm{ml}$ yeast tRNA] containing a ${ }^{35} S$-labeled oligodeoxyribonucleotide probe complementary to nucleotides 319-351 of rat prepro-TRH mRNA (Lechan et al., 1986). The probe was labeled using terminal dcoxynuclcotidyl transferase (Bcthesda Rescarch Labs) and $\alpha$-thio ${ }^{35}$ S-dATP (New England Nuclear), purified by gel filtration, and added to the hybridization buffer $\left(5 \times 10^{6} \mathrm{cpm} / \mathrm{ml}\right)$. As a control for probe specificity, RNA blot (Northern) analysis of brainstem RNA demonstrated that this oligonucleotide hybridized under similar stringency to only a single 1.6 kilobase RNA species (not shown; Szymeczek et al., 1990; Millhorn et al., 1991), as expected for TRH mRNA (Segerson et al., 1987). Furthermore, the distribution of TRH mRNA-containing cells we found in the adult rat with this probe (not shown) was essentially identical to that demonstrated previously (Segerson et al., 1987).

Following hybridization, the buffer was decanted, the sections were dipped twice in $1 \times \mathrm{SSC}$ at $55^{\circ} \mathrm{C}$ and washed in $1 \times \mathrm{SSC}$ at $55^{\circ} \mathrm{C}$ and at $22^{\circ} \mathrm{C}$ for $1 \mathrm{hr}$ each. The sections were dipped briefly in distilled water and $95 \%$ ethanol, air dried, and either apposed to Hyperfilm $\beta$-max $\mathrm{x}$-ray film (Amersham) in cassettes for periods of 7-14 $\mathrm{d}$ or dipped in liquid emulsion (Kodak NTB-2), air dried, and exposed for 2-4 weeks at $4^{\circ} \mathrm{C}$. The emulsion was developed in D 19 and fixed with Kodafix (both Kodak). Sections were counterstained with toluidine blue $(0.25 \%)$, coverslipped, and analyzed with a Nikon Optiphot microscope equipped with bright-field and dark-field condensers. A computerized image analysis system (Image Pro Plus, Media Cybernetics) was used for quantitation of hybridization signal. Sections (one section/animal) used for quantitation were taken from a representative experiment (one animal/ time point) and were from approximately the same rostrocaudal position in the medulla oblongata (region just caudal to transition from fourth ventricle to central canal). The 10 most heavily labeled cells in the section were circumscribed and the computer determined the number of silver grains and pixels contained within the indicated area. Data are expressed as the density of silver grains (grains $/ 10^{4}$ pixels) over labeled cells. The statistical significance of age-related changes in silver grain density were evaluated by analysis of variance (ANOVA). Multiple comparisons were made with the Bonferroni modification of the $t$ test (Wallenstein et al., 1980) and were considered significant if $P<0.05$.

Immunohistochemistry-TRH. Sprague-Dawley rats were taken at each of the postnatal ages listed above (two at each age), anesthetized [by hypothermia $(<\mathrm{P} 14)$ or with ketamine/xylazine as above] and perfused transcardially with $4 \%$ paraformaldehyde containing $0.3 \%$ picric acid (Zamboni and DeMartino, 1967). The brain was removed, immersed in the same fixative at $4^{\circ} \mathrm{C}$ for $90 \mathrm{~min}$, and then placed in $10 \%$ sucrose in PB overnight at $4^{\circ} \mathrm{C}$. Coronal sections $(14 \mu \mathrm{m})$ of the medulla oblongata through the hypoglossal nucleus were cut on a microtome in a cryostat, thaw mounted onto twice-gelatin-coated glass slides, and 
rinsed in $0.01 \mathrm{~m}$ PBS. The sections were processed for immunohistochemical detection of TRH using a modification of the indirect immunofluorescence technique (Coons, 1958). Briefly, the sections were incubated with a rabbit polyclonal antisera to TRH (obtained from $\mathrm{T}$. Gorcs, Semmelweis University, Budapest, Hungary), diluted 1:400 in PBS containing $0.3 \%$ Triton X-100, $0.1 \mathrm{mg} / \mathrm{ml} \mathrm{NaN}_{3}, 0.2 \mathrm{mg} / \mathrm{ml} \mathrm{bac-}$ itracin, overnight at $4^{\circ} \mathrm{C}$ in a humidified chlamber. After rinsing extensively in PBS, sections were incubated with fluorescein isothiocyanate (FITC)-conjugated goat anti-rabbit immunoglobulins (1:40; Boehringer Mannheim) for $\mathrm{l} \mathrm{hr}$ at $22^{\circ} \mathrm{C}$. They were rinsed in PBS, coverslipped in glycerol:PBS (3:1) containing $0.1 \% p$-phenylenediamine, and examined and photographed with a Nikon Optiphot fluorescent microscope equipped with filter combinations for viewing FITC. The specificity of the antisera used in these experiments has previously been established (Merchenthaler et al., 1988). Nevertheless, we performed a number of control experiments with this antisera to verify that the immunostaining was specific for TRH. Thus, in preliminary experiments we found an appropriate distribution of immunostained cells in brains of colchicinetreated rats with this TRH antisera (e.g., hypothalamic paraventricular nucleus, lateral hypothalamic area, brainstem raphe nuclei; Tsuruo et al., 1987; Merchenthaler et al., 1988). Furthermore, we found that preadsorption of the primary antisera with $10 \mu \mathrm{M}$ TRH abolished all immunostaining and we found no immunostaining when the primary antisera was omitted from the immunohistochemical procedure.

Autoradiography $-T R H$ receptor. To determine changes in TRH binding in nXII during the early postnatal period we performed two experiments. In one, we compared binding of a radiolabeled TRH analog in rats at two time points ( $\mathrm{P} 0$ and $\mathrm{P} 21)$ and in the other we performed a more extensive time series (P0, P7, P14, and P21). Rats were rapidly decapitated $(<\mathrm{P} 14)$, or anesthetized (as above) and decapitated. Brains were removed quickly, and the brainstem blocked and frozen onto cryostat chucks over dry ice. Coronal sections $(30 \mu \mathrm{m})$ were cut in a cryostat, thaw mounted onto twice-gelatin-coated slides, and stored at $-80^{\circ} \mathrm{C}$. Sections were processed for TRH receptor autoradiography essentially as described by Manaker and Rizio (1989). Sections were warmed to room temperature $(\sim 15 \mathrm{~min})$ and equilibrated in $50 \mathrm{~mm}$ Tris- $\mathrm{HCl}$, $5 \mathrm{~mm} \mathrm{MgCl}, 0.2 \% \mathrm{BSA}(\mathrm{pH} 7.4)$ at $22^{\circ} \mathrm{C}$ for $10 \mathrm{~min}$. Sections were then incubated in $200 \mu \mathrm{l}$ of the same buffer, but containing $20 \mu \mathrm{M}$ bacitracin and $11 \mathrm{nM}{ }^{3} \mathrm{H}-3$-methyl-his ${ }^{2}-\mathrm{TRH}\left({ }^{3} \mathrm{H}-\mathrm{MeTRH} ; 87 \mathrm{Ci} / \mathrm{mmol}\right.$; New England Nuclear) for $2 \mathrm{hr}$ at $4^{\circ} \mathrm{C}$. Nonspecific binding, determined in the presence of $10 \mu \mathrm{M} \mathrm{MeTRH} \mathrm{(Peninsula),} \mathrm{was} \mathrm{negligible} \mathrm{at} \mathrm{all}$ postnatal ages examined. Sections were washed in buffer $(4 \times 30 \mathrm{sec})$, dipped in distilled water (both ice-cold), air dried, and placed in a cassette apposed to ${ }^{3} \mathrm{H}$-sensitive $\mathrm{x}$-ray film (Amersham) for periods of 2-5 months. After the film was developed, the sections were counterstained (toluidine blue, $0.25 \%$ ), and the extent of specific ${ }^{3} \mathrm{H}-\mathrm{MeTRH}$ binding in the nXII was determined densitometrically from the film autoradiographs. The nXII was located in the Nissl-stained sections, and the optical density (OD) of that region in the corresponding autoradiograph was determined (Image Pro Plus, Media Cybernetics). Background OD (over the medial longitudinal fasciculus) was determined in each section and subtracted. Measurements were made in quadruplicate (i.e., four sections from one animal at each time point) and evaluated statistically by ANOVA and a Bonferroni modification of the $t$ test $(P$ $<0.05$ ).

Electrophysiology. Electrophysiological experiments were performed in vitro using brainstem slices from rats obtained at different postnatal ages (P0-P21). Brainstem slices were prepared essentially as described previously (Viana et al., 1990; Bayliss et al., 1992a). Animals were either rapidly decapitated ( $<\mathrm{P} 14)$ or anesthetized (ketamine/xylazine, as above), artificially ventilated $\left(95 \% \mathrm{O}_{2}, 5 \% \mathrm{CO}_{2}\right.$, carbogen), and decapitated. The brainstem was exposed, blocked, and removed under a steady stream of ice-cold Ringer's or sucrose-containing Ringer's solution (see below for composition of solutions). The tissue block was glued to a Teflon platform and to an agar support using cyanoacrylate glue, submerged in ice-cold Ringer's and cut at $400-500 \mu \mathrm{m}$ with a Vibroslice (Campden). Slices were transferred to an interface-type tissue chamber perfused with oxygenated Ringer's and gassed with humidified carbogen at $33 \pm 1^{\circ} \mathrm{C}$. The Ringer's solution contained (mM) NaCl, 130; $\mathrm{KCl}, 3 ; \mathrm{MgCl}_{2}, 2$; $\mathrm{CaCl}_{2}, 2 ; \mathrm{NaH}_{2} \mathrm{PO}_{4}, 1.25 ; \mathrm{NaHCO}_{3}, 26$; and glucose, 10 . Sucrose-containing Ringer's, made by substitution of $260 \mathrm{~mm}$ sucrose for $\mathrm{NaCl}$, was used in some experiments with older animals to improve viability of the slices (Aghajanian and Rasmussen, 1989). TRH (Peninsula) was prepared as a $10 \mathrm{~mm}$ frozen stock solution and added to the perfusate at a final concentration of $1-10 \mu \mathrm{M}$. Nominally calcium-free solutions containing $2 \mathrm{~mm} \mathrm{Mn}{ }^{2+}$ were made by equimolar substitution of $\mathrm{MnCl}_{2}$ for $\mathrm{CaCl}_{2}$. Tetrodotoxin (TTX; Calbiochem) was prepared as a $200 \mu \mathrm{M}$ stock and added to the perfusing media at final concentrations of $0.5-$ $2 \mu \mathrm{M}$.

Intracellular recordings were obtained from neurons within nXII using microelectrodes $(10-100 \mathrm{M} \Omega)$ filled with $3 \mathrm{M} \mathrm{KCl}$. Electrical recordings were made with an Axoclamp 2A (Axon) using active bridge, discontinuous current-clamp, and single-electrode voltage-clamp modes. The headstage output was continuously monitored on a separate oscilloscope to set capacitance compensation and maximize sampling frequency according to published procedures (Finkel and Redman, 1985).

In brainstem slices from older animals we recorded from cells within the clearly visible boundaries of $n X I I$. We refer to the recorded neurons as HMs because it has been established previously that the overwhelming majority of neurons in $\mathrm{nXII}$ of adult animals are motoneurons (Haddad et al., 1990; Viana et al., 1990). In slices from the youngest animals, however, nXII was often difficult to visualize. Therefore, in those cases, the location of $\mathrm{nXII}$ was determined by first establishing the position of neurons of the dorsal motor nucleus of the vagus (dmnX), which display electrophysiological properties distinct from HMs (e.g., longer-duration action polentials and afterpotentials, prominent delay to the first spike following hyperpolarizing prepulses; Yarom et al., 1985; Sah and McLachlan, 1992); recordings were then made immediately ventral to dmnX. In addition, we only recorded from cells located ventrolateral to the central canal that had a stable resting potential $\leq-60$ $\mathrm{mV}$ and an overshooting action potential and that fired repetitively in response to depolarizing current pulses. These properties are characteristic of identified HMs that were recorded in a separate study of neonatal rats under identical conditions; neurons that had these properties were identified as HMs by either antidromic activation or intracellular staining (Viana et al., in press). In fact, all neurons that were stained were located within $\mathrm{nXII}$ and all were identified morphologically and/or anatomically as HMs (i.e., large multipolar somata with axons coursing ventrally toward the hypoglossal nerve rootlet; Viana et al., in press). Therefore, we are extremely confident that the neonatal cells recorded in the present study under identical conditions and with similar electrical properties are, indeed, HMs.

Membrane current and voltage were monitored on a storage oscilloscope and a pen recorder, and stored on an FM tape recorder for offline analysis either with a digital oscilloscope (Gould) and a microcomputer using laboratory-developed software or using a Labmaster TL-1 interfaced with a microcomputer running pCLAMP software (Axon). Data collected to evaluate intrinsic properties of HMs and to determine the effect of TRH on HMs included membrane potential $\left(E_{M}\right)$ at rest, input conductance $\left(G_{N}\right)$, spike threshold, membrane time constant $\left(\tau_{M}\right)$, cell capacitance $\left(C_{1}\right)$, amplitude of TRH-sensitive current $\left(I_{\text {TRH }}\right)$, and TRH current amplitude normalized to cell capacitance (current density, $I_{\mathrm{TRH}} /$ $\left.C_{n}\right)$ or to resting $G_{A}\left(I_{\text {TRH }} / G_{\text {rest }}\right)$. The effect of TRH on $G_{N}$ was measured in all cells. Resting $G_{N^{\prime}}\left(G_{\text {ress }}\right)$ was taken as the reciprocal of the slope of a regression line fitted to the peak voltage responses to a family of current pulses. A single exponential fit of the voltage response to the largest hyperpolarizing current pulse that did not produce a significant depolarizing "sag" in the voltage trajectory was used to estimate $\tau_{M}$. Cell capacitance was calculated as the product of $G_{N}$ and $\tau_{M}$. The magnitude of $I_{\text {TRH }}$ was determined as the amount of steady injected current necessary to return $E_{M}$ at the peak of TRH-induced depolarization back to the control level (i.e., before TRH). Multivariate analysis of variance (ANOVA) and a Bonferroni $t$ test were used to determine significance of age and response type (typical vs atypical; see below) effects on the response to TRH $(P<0.05)$.

\section{Results}

In situ hybridization-TRH $m R N A$

The principal cell groups in the adult rat brainstem that express TRH are RPa and ROb (Hökfelt et al., 1975a,b; Johansson et al., 1981; Segerson et al., 1987). We used in situ hybridization to determine the developmental time course of TRH mRNA cxpression in $\mathrm{RPa}$ and $\mathrm{ROb}$. Film autoradiographs of tissue sections in the region of $\mathrm{RPa}$ and $\mathrm{ROb}$ from animals at different postnatal ages are shown in Figure 1 (see Fig. $I F$ for locations of $\mathrm{RPa}$ and $\mathrm{ROb}$ ). At PO, there was little or no evidence of 

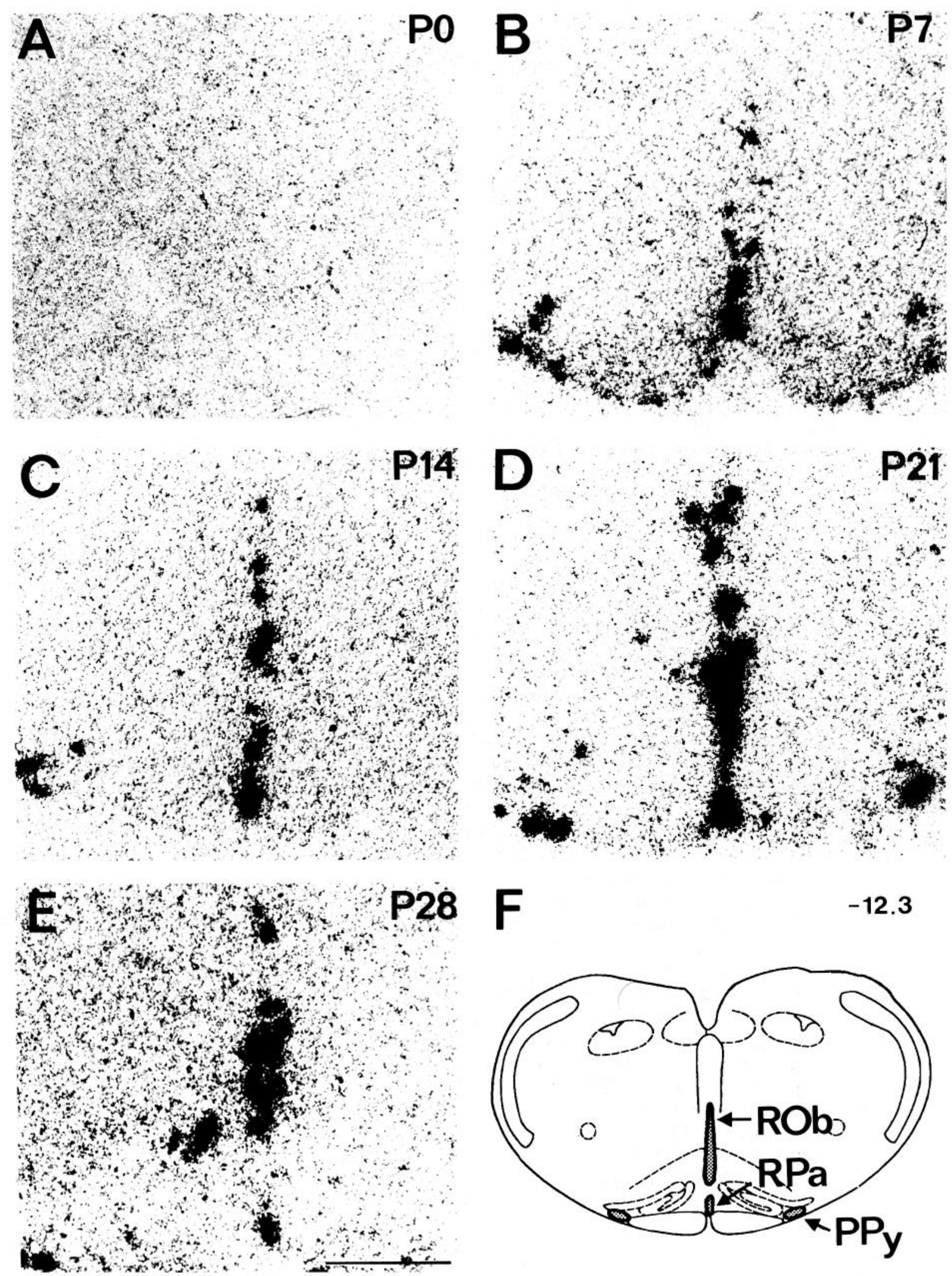

$-12.3$

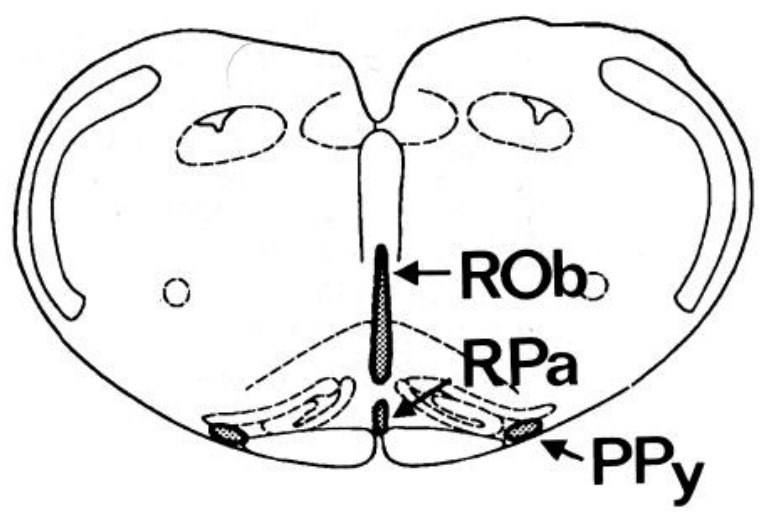

Figure 1. TRH mRNA expression increases postnatally in caudal raphe nuclei. Sections of brainstem obtained from rats at different postnatal ages were incubated with an ${ }^{35} \mathrm{~S}$-labeled DNA probe complementary to TRH precursor mRNA and apposed to autoradiographic film. Bright-field photomicrographs of autoradiographs from approximately the same rostrocaudal level from $\mathrm{P} 0(A), \mathrm{P} 7(B), \mathrm{P} 14(C), \mathrm{P} 21(D)$, and P28 $(E)$ animals are shown. A schematic illustrating the location of raphe obscurus $(R O b)$ and raphe pallidus $(R P a)$ in the rat brainstem is also provided $(F$; adapted from Paxinos and Watson, 1986). There is very little evidence for expression of TRH mRNA in ROb and RPa in the P0 brainstem ( $A)$. Raphe neurons have clearly begun to express TRH mRNA by P7 $(B)$ and continue to do so through P28. Exposure time was the same for all panels ( 7 d). Scale bar, $500 \mu \mathrm{m}$ (does not apply to $F$ ). 

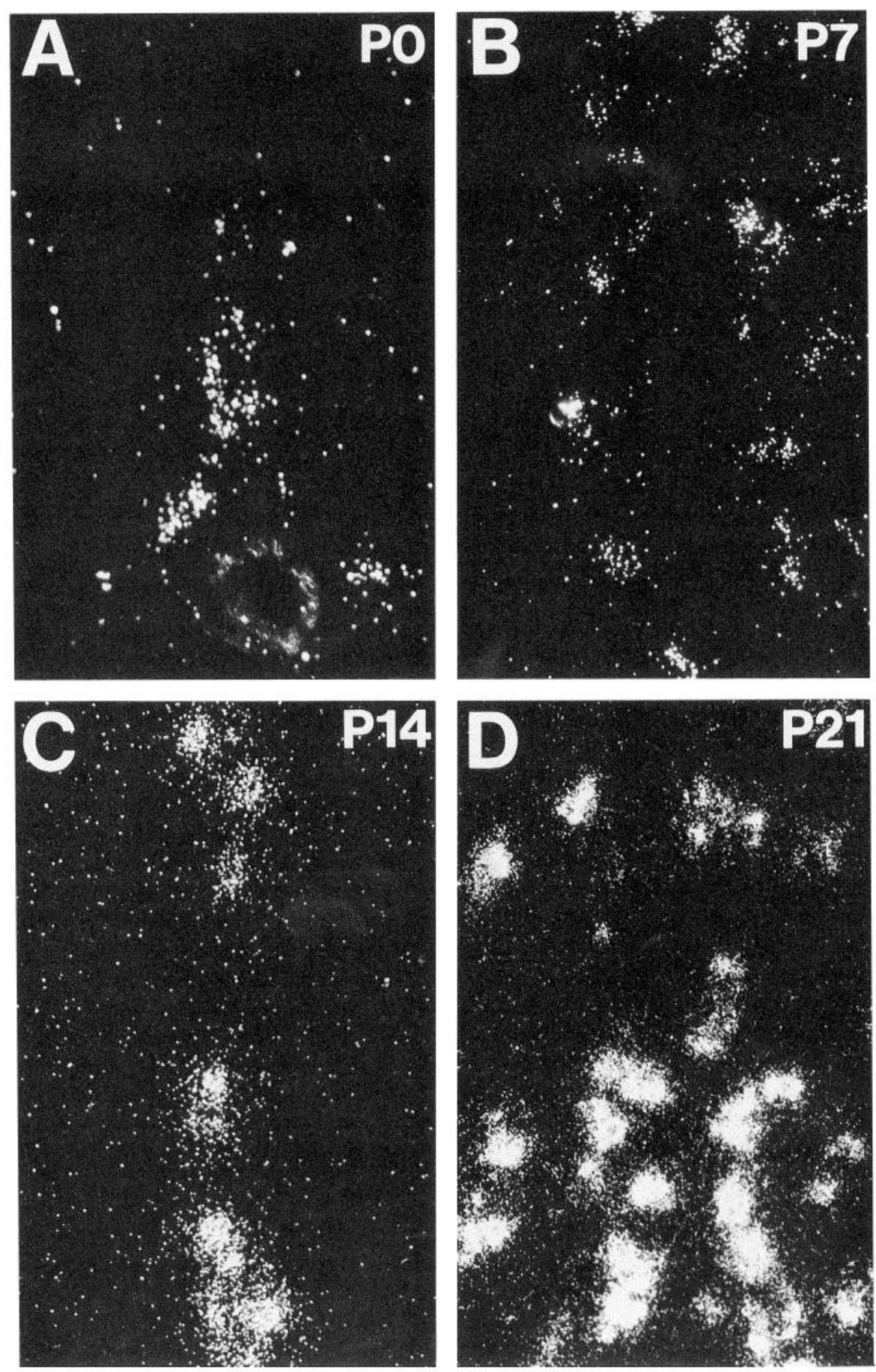

Figure 2. Expression of TRH mRNA in raphe neurons during postnatal development. Sections of brainstem obtained from rats at different postnatal ages were incubated with an ${ }^{35} \mathrm{~S}$-labeled DNA probe complementary to TRH precursor mRNA and dipped in liquid emulsion. Dark-field photomicrographs from approximately the same rostrocaudal level are shown. We found only very few labeled cells in sections from animals at $\mathrm{P} 0(A)$ and the level of TRH expression (i.e., density of silver grains) was extremely low. Already by P7 $(B)$, and through P14 $(C)$ and P21 $(D)$, the silver grain density and the number of cells expressing TRH had increased. Exposure time was the same for all panels $(\sim 3$ weeks). Magnification: $A$ and $B, 80 \times ; C$ and $D, 50 \times$.

expression of TRH mRNA in these autoradiographs (Fig. 1 $A$ ). By P7, TRH mRNA was apparent in the regions of $\mathrm{RPa}$ and $\mathrm{ROb}$ including the parapyramidal component of $\mathrm{RPa}$ (Fig. $1 B$ ). TRH mRNA was expressed at high levels by P14, P21, and P28 (Fig. $1 C-E$ ). The apparent absence of hybridization in the very young animal (P0) cannot be attributed to a peculiarity of applying in situ hybridization analyses to tissue from neonates. In a separate in situ hybridization study, we found the expression of somatostatin mRNA in $\mathrm{nXII}$ was highest at P0 and decreased during the early postnatal period (Seroogy et al., 1991), a trend opposite to that reported here for TRH mRNA.

We examined emulsion-dipped slides in order to determine the pattern of TRH mRNA expression in individual raphe neurons; dark-field photomicrographs of $\mathrm{RPa}$ from emulsion-dipped slides are shown in Figure 2. Microscopic evaluation allowed detection of some TRH mRNA-containing cells in sections from P0 animals (Fig. 2A), but they were only infrequently encountered, and the density of silver grains over the cells was low. In sections from older animals (P7, P14, and P21 in Fig. 2B-D, respectively), progressively more TRH mRNA-synthesizing cells were found, and those cells were labeled with a higher density of silver grains. Quantitation of developmental changes in TRH mRNA, achieved by computer-assisted counting of silver grains overlying individual raphe neurons, is shown in Figure $5 \mathrm{~A}$. Sil- 

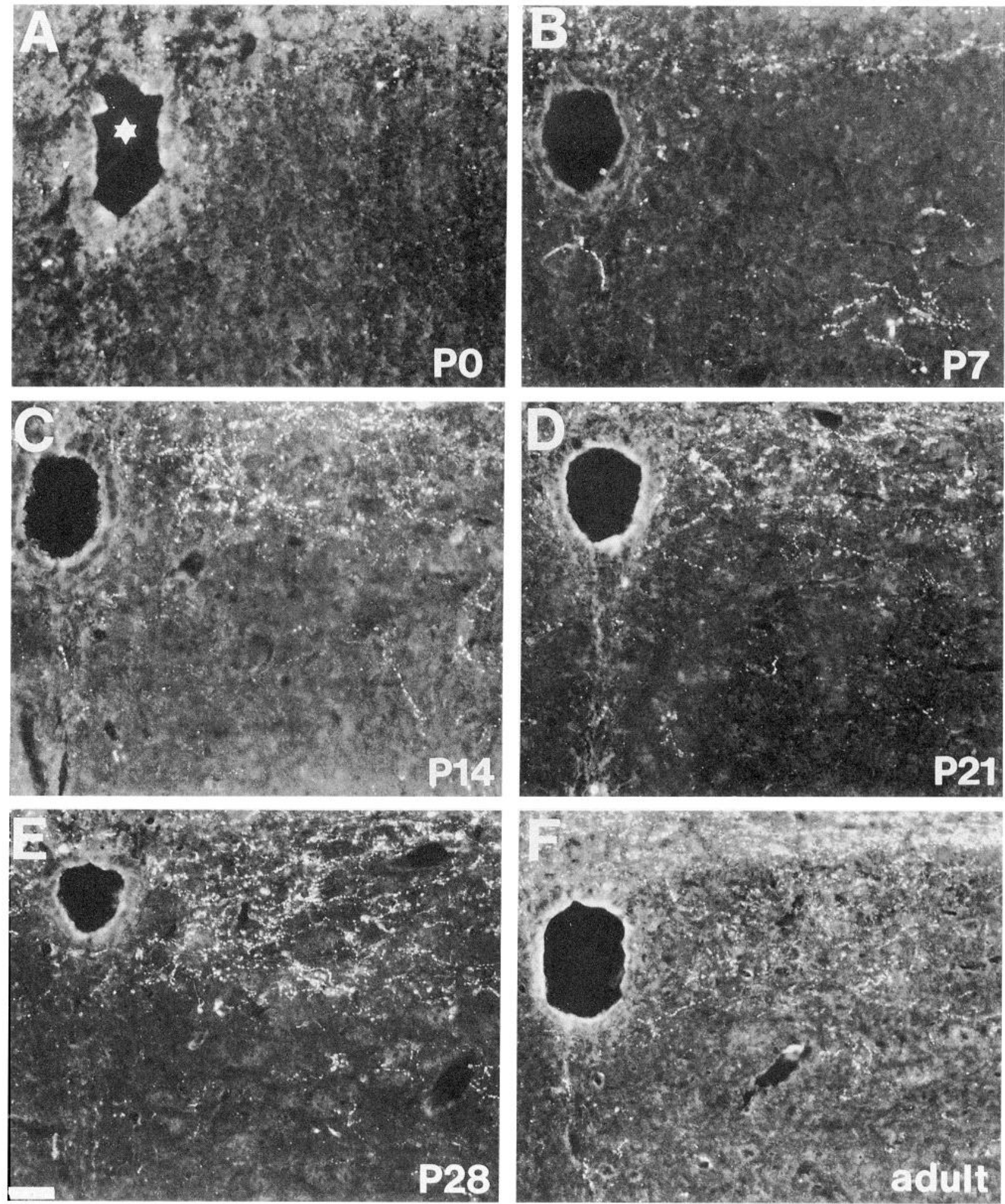

Figure 3. Density of TRH-IR fibers in nXII increases postnatally. Fluorescence photomicrographs show TRH-IR fibers in nXII (located lateral and ventrolateral to the central canal; marked with a star) of P0 $(A), \mathrm{P} 7(B), \mathrm{P} 14(C), \mathrm{P} 21(D), \mathrm{P} 28(E)$, and adult $(F)$ animals. Very few fibers were found in $\mathrm{nXII}$ of the P0 rat $(A)$. A greater number of fibers were present in nXII of the P7 animal $(B)$ and further increases were apparent in the older animals. Note that the dense plexus of TRH-IR fibers in dmnX immediately above $\mathrm{nXII}$ in the adult $(F)$ is also absent in the P0 brainstem. Scale bar, $\sim 50 \mu \mathrm{m}$. 


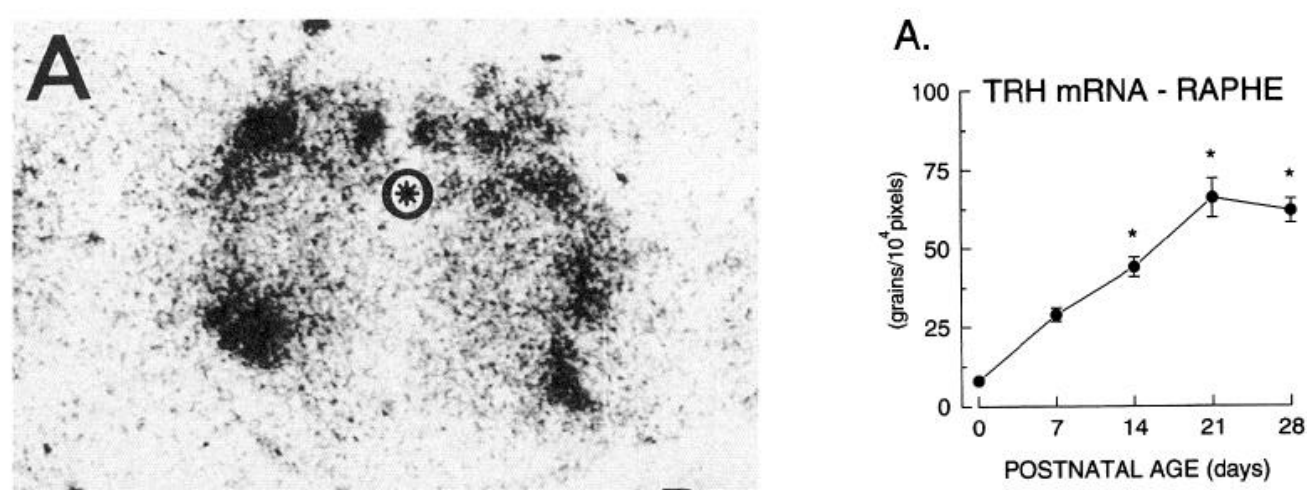

B.

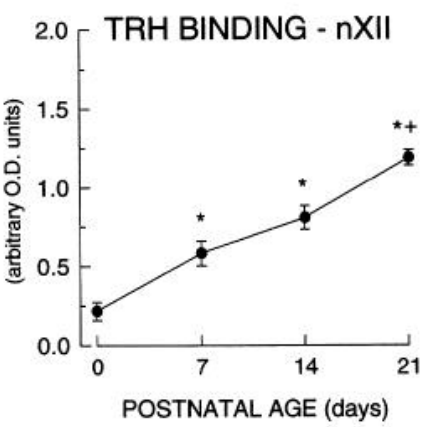

Figure 5. Expression of TRH and its receptor increase postnatally in rat brainstem. Sections of brainstem obtained from rats at different postnatal ages were incubated with an ${ }^{35}$ S-labeled DNA probe complementary to TRH precursor mRNA $(A)$ or with ${ }^{3} \mathrm{H}-\mathrm{MeTRH}(B)$ and processed by liquid emulsion or film autoradiography, respectively. $A$, The mean density of silver grains (grains $/ 10^{4}$ pixels) overlying individual raphe neurons $(n=10)$ was determined at each age (see Materials and Methods). Silver grain density increased significantly with age $\left(F_{4,45}=\right.$ 47.4, $P<0.0001$ ). Pairwise comparison revealed that no further statistically significant increases in grain density occurred after P14. $B$, OD overlying the region of nXII was determined $(n=4)$ at each age as a measure of receptor binding; background over the medial longitudinal fasciculus was subtracted (see Materials and Methods). ${ }^{3} \mathrm{H}-\mathrm{MeTRH}$ binding increased with postnatal age $\left(F_{3.12}=38.3, P<0.0001\right)$. Pairwise comparison revealed that binding was significantly increased at all time points after P0 $\left(^{*}\right)$; in addition, levels of binding were higher at P21 than at $\mathrm{P} 7(+)$.

ver grain density (mean of 10 cells) as a function of age was determined from a representative experiment. The data indicate that levels of TRH mRNA in individual cells increased significantly $\left(F_{4.45}=47.4, P<0.0001\right)$ from birth to P14; no further statistically significant changes in silver grain density occurred after P14. This analysis likely underestimates the true increase in TRH expression in the population of raphe neurons as it does not include the contribution resulting from the increased number of cells expressing TRH. Nevertheless, it is clear from these data that levels of TRH mRNA in raphe neurons increased substantially over the early postnatal period.

\section{Immunohistochemistry $-T R H$}

In the adult rat $\mathrm{nXII}$ is innervated by TRH-containing fibers (Hökfelt et al., 1975a,b) that emanate from cell bodies located in RPa and ROb (Lynn et al., 1991). We used an immunohistochemical approach to determine if the developmental changes in TRH mRNA levels in RPa and $\mathrm{ROb}$ are reflected in the density of TRH innervation in $\mathrm{nXII}$. Representative results from one of these experiments are shown in Figure 3. The photomicrographs from sections just caudal to obex show nXII located immediately lateral and ventrolateral to the central canal (star in Fig. $3 A$ ). In the $\mathrm{P} 0$ animal (Fig. $3 A$ ), there were very few TRH-IR fibers in nXII throughout its entire extent. Note also the paucity of TRH-IR fibers in the dmnX located immediately dorsal to nXII. A slightly higher density of immu-

diography. Bright-field photomicrographs of autoradiographs from $\mathrm{P} 0$ $(A), \mathrm{P} 7(B), \mathrm{P} 14(C)$, and $\mathrm{P} 21(D)$ are shown. The location of the central canal, determined from the corresponding Nissl-stained section, is indicated in $A$ (encircled asterisk). nXII, indicated with double arrows in $D$, is located immediately lateral and ventrolateral to the central canal. The postnatal increase in receptor binding in $\mathrm{nXII}$ is apparent. Exposure time was the same for all panels ( $\sim$ months). Scale bar, $1 \mathrm{~mm}$.

Figure 4. TRH binding in $\mathrm{nXII}$ increases during postnatal development. Sections of brainstem obtained from rats at different postnatal ages were incubated with ${ }^{3} \mathrm{H}-\mathrm{MeTRH}$ and processed for film autora- 

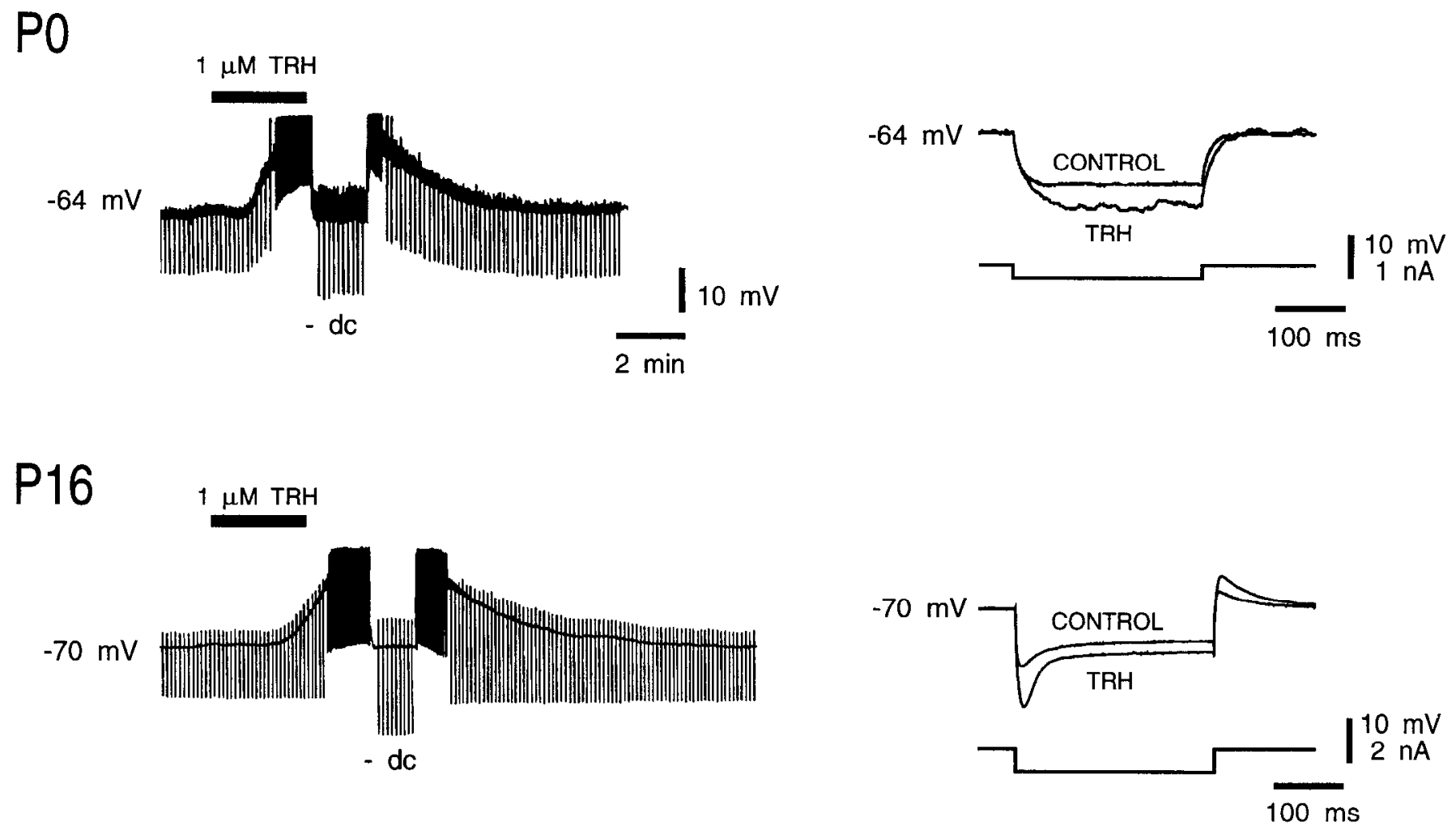

Figure 6. "Adult-like" responses of neonatal HMs to TRH. Intracellular recordings were made from neonatal $\mathrm{HMs}[\mathrm{P} 0(<1 \mathrm{hr}$ old $)$ and $\mathrm{P} 16]$ in a brainstem slice preparation during application of $1.0 \mu \mathrm{M} \mathrm{TRH}$ (solid bar). Downward deflections in the membrane voltage trace reflect responses to constant amplitude current pulses $(-0.30$ and $-1.0 \mathrm{nA}$, respectively). The chart records (left) show that TRH caused the HMs to depolarize beyond firing threshold (spikes truncated by the pen recorder). Near the peak of the response, steady hyperpolarizing current was applied through the microelectrode $\left(I_{\mathrm{TRH}}=-0.16\right.$ and $-0.88 \mathrm{nA}$, respectively) to return the cell to its original membrane potential. Voltage responses to the current pulses delivered at that potential in control and in TRH are shown on an expanded time scale (right; digital average of eight responses). The voltage deflections are clearly enhanced by TRH, indicating a decrease in $G_{N}$ (to $70 \%$ and $55 \%$ of control, respectively). Responses such as these were typical of those observed prcviously in adult HMs (Bayliss et al., 1992a). Note the higher $G_{\text {rest }}$ in the P16 HM as evidenced by a similar peak voltage response to a larger-amplitude current pulse. Note also the presence of depolarizing "sag" in the voltage response of the P16 HM. Resting membrane potential (RMP) for PO HM was $-67 \mathrm{mV}$; cell held at $-64 \mathrm{mV}$ in control with $0.17 \mathrm{nA} \mathrm{DC}$; RMP for P16 HM was $-73 \mathrm{mV}$; cell held at -70 $\mathrm{mV}$ initially with $0.54 \mathrm{nA} \mathrm{DC}$.

noreactive fibers was noted at $\mathbf{P 7}$ (Fig. $3 B$ ), and substantially more fibers were apparent in sections from older neonatal animals (P14, P21, and $\mathrm{P} 28$ in Fig. $3 C-E$, respectively) and in adult rat (Fig. $3 F$ ). The TRH-IR fibers were distributed mostly in the dorsal aspects of $\mathrm{nXII}$ and were located immediately subjacent to a more dense plexus of TRH-IR fibers in $\mathrm{dmnX}$, a pattern similar to the distribution of 5-HT-IR fibers (Aldes et al., 1988). Results from another experiment were essentially identical. Thus, the developmental changes in TRH mRNA observed at the source ( $\mathrm{RPa}$ and $\mathrm{ROb}$ ) are reflected in levels of immunoreactive peptide in the target (nXII).

\section{Autoradiography $-T R H$ receptor}

To determine if the postnatal increases in TRH expression in raphe neurons and TRH innervation of nXII are matched by changes in TRH receptors in $\mathrm{nXII}$, we investigated the level of ${ }^{3} \mathrm{H}$-MeTRH binding at different postnatal ages. Film autoradiographs from one such experiment are presented in Figure 4. At $\mathrm{PO}$ (Fig. $4 A$ ) there was essentially no TRH binding in $\mathrm{nXII}$, which was located bilaterally, immediately lateral and ventrolateral to the central canal (marked by encircled asterisk) in the corresponding Nissl-stained section (not shown). By P7 (Fig. $4 B$ ) there was a substantial increase in TRH binding in $\mathrm{nXII}$.
Levels of TRH binding continued to increase further through P14 (Fig. 4C) and P21 (Fig. 4D). The postnatal changes in ${ }^{3} \mathrm{H}$ MeTRH binding in this experiment were quantitated by measuring OD of the autoradingraphs within the area of nXII (determined from Nissl-stained sections) and plotted as a function of postnatal age (Fig. 5B). TRH binding increased significantly with postnatal age $\left(F_{3,12}=38.3, P<0.0001\right)$. Pairwise comparison revealed that the level of binding at all time points was significantly greater than at PO and differences in binding between P7 and P21 were also significant. Similar results were obtained in a separate experiment in which we compared levels of ${ }^{3} \mathrm{H}$-MeTRH binding in $\mathrm{nXII}$ in brainstem sections from $\mathrm{PO}$ and P21 animals. These data indicate that a developmental increase in TRH receptor binding takes place in $\mathrm{NXII}$ that closely parallels increases in TRH innervation of $\mathrm{nXII}$ and the expression of TRH mRNA in ROb and RPa.

\section{Electrophysiology}

Since TRH innervation of $\mathrm{XXI}$ and the amount of TRH binding in $\mathrm{nXII}$ are developmentally regulated, we determined if the response of HMs $(n=42)$ to application of TRH also changes throughout the early postnatal period. Representative examples of TRH effects on HMs from neonatal rats are shown in Figures 
A.
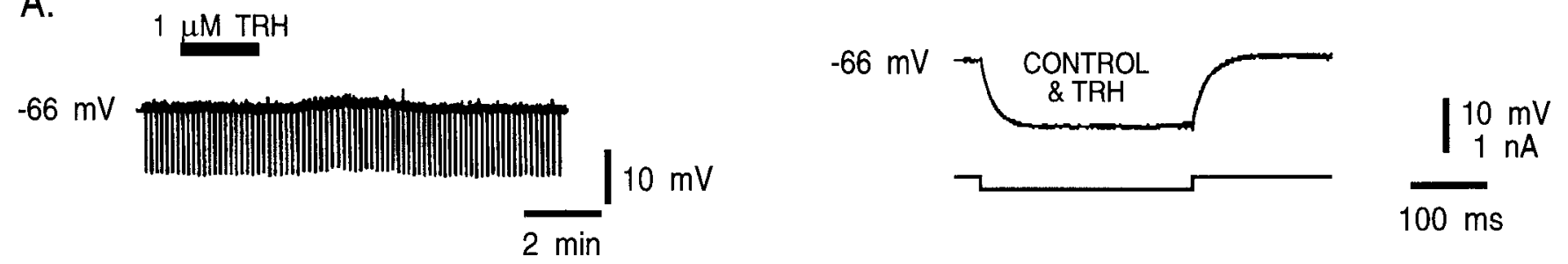

\section{B1. CONTROL}

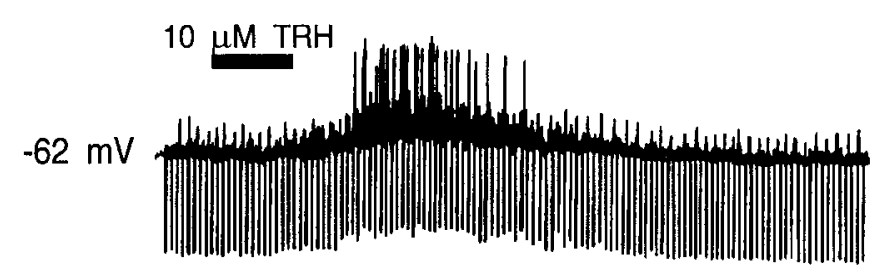

C1. CONTROL

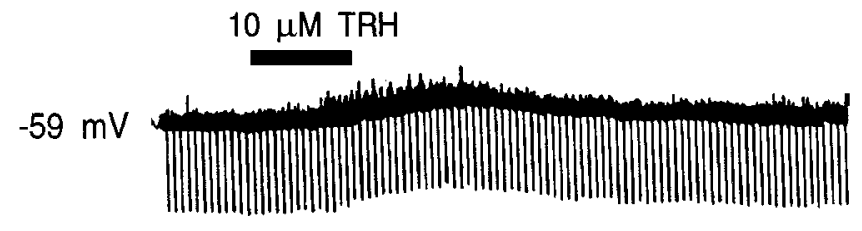

B2. $2 \mathrm{mM} \mathrm{Mn}^{2+}$ zero $\mathrm{Ca}^{2+}$

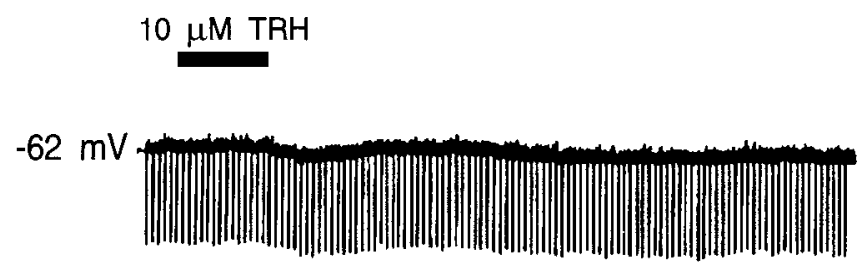

C2. $2 \mu \mathrm{M} \mathrm{TTX}$

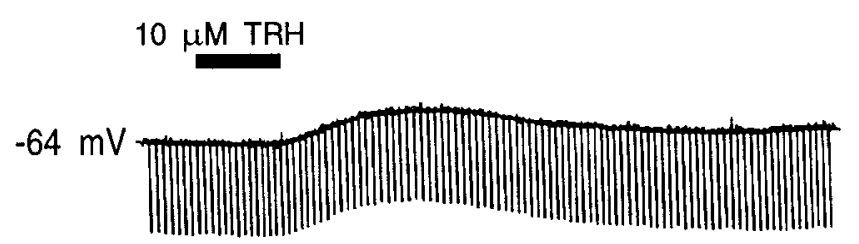

Figure 7. The response of neonatal HMs to TRH was variable. Intracellular recordings were made from neonatal HMs (all P2) during application of TRH (solid bars). Negative deflections in chart records are membrane voltage responses to constant amplitude hyperpolarizing current pulses $(0.2,0.25$, and $0.4 \mathrm{nA}$ in $A-C$, respectively). $A$, TRH did not depolarize this $\mathrm{HM}$ and the voltage responses (right) to the constant amplitude current pulses indicate that TRH had no effect on $G_{N} . B 1$, TRH caused a depolarization in this HM that was associated with a substantial increase in synaptic activity (thickening of the trace), but that was not associated with a change in $G_{N}$. Action potentials (truncated) at the peak of the response were associated with the larger synaptic potentials. $B 2$, The response shown in $B 1$ was synaptically mediated as TRH was without effect on this

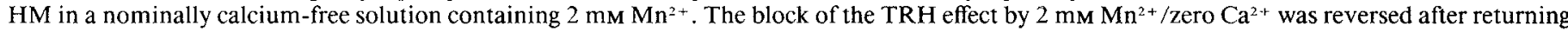
the cell to normal perfusate (not shown). $C l, \mathrm{TRH}$ caused a slight depolarization in this HM but there was no effect of TRH on $G_{N}$ (note that the voltage deflections are not bigger in TRH). $C 2$, In contrast to the response depicted in $B$, however, this effect of TRH was apparently direct. In a Ringer's solution containing $2 \mathrm{mM}$ TTX, which clearly decreased synaptic activity, TRH still depolarized the HM. This response was again independent of any change in $G_{N}$. The responses of these three HMs were similar inasmuch as they were independent of any effect on $G_{N}$. Because such responses were unlike any measured in adult HMs they were considered atypical. RMPs of these neurons were $-66 \mathrm{mV},-72 \mathrm{mV}$, and -64 $\mathrm{mV}$, respectively.

6 and 7. Chart recordings of membrane potential in Figure 6 (left panels) show the effect of TRH when applied to an HM from a P0 and a P16 animal. The negative-going deflections in $E_{M}$ resulted from injection of constant amplitude hyperpolarizing current pulses. In these cases, TRII caused the cells to depolarize to beyond firing threshold; at the peak of the response, steady hyperpolarizing current (equal to $I_{\mathrm{TR} I} ;-\mathrm{dc}$ ) was injected to return the cell to its original potential. The voltage response to the current pulses was greater at the peak of the response to TRH than in the control period (Fig. 6, right panels), indicating that TRH decreased $G_{N}$ of the cells. In addition, note that a substantially larger amplitude current pulse was required in the P16 HM to elicit peak voltage responses similar to the P0 $\mathrm{HM}$, reflecting the increase in $G_{\text {rest }}$ we found in these cells during postnatal development $\left(F_{4,36}=20.1, P<0.0001\right.$; see also Haddad et al., 1990; Viana et al., in press). Also note that the prominent depolarizing "sag" in the voltage trajectory of the P16 HM is largely absent in that of the P0 HM, reflecting the postnatal increase in the hyperpolarization-activated inward current, $I_{h}$ (Bayliss, et al., in press). Despite these differences in the intrinsic properties of the P0 and P16 HMs, the nature of their responses to TRH were similar.

We found the type of response illustrated in Figure 6 in $67 \%$ of our sample of neonatal HMs (28 of 42) and in all cells from animals older than P11. In a voltage-clamp experiment from a different HM that responded in this manner (P6; not shown), instantaneous current-voltage relationships obtained before and during TRH intersected (i.e., $I_{\mathrm{TRH}}$ reversed) at $-110 \mathrm{mV}$, slightly negative to the potassium equilibrium potential as reported earlier for adult HMs (Bayliss et al., 1992a). Moreover, analysis of input-output relationships in a subset of these neurons $(n=5)$ revealed a leftward, parallel shift in the steady-state firing frequency response to injected current, also reported earlier in our study of adult HMs (Bayliss et al., 1992a). Therefore, this type of response was characteristic of those of adult HMs reported previously (Rekling, 1990; Bayliss et al., 1992a) and demonstrates that even at a very early age some cells respond in a manner similar to (typical of) adult HMs.

A number of neonatal HMs (33\%; all $\leq \mathrm{P} \perp 1)$, however, responded in a different manner (Fig. 7). As depicted in Figure 

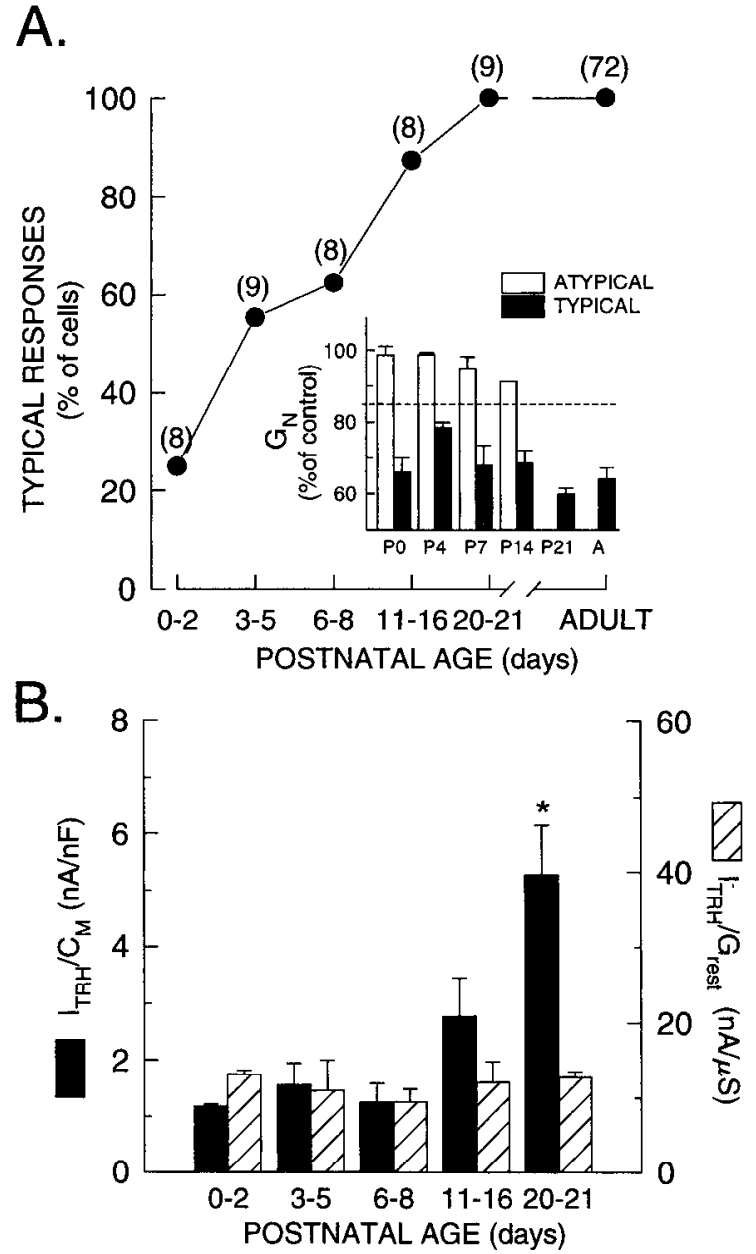

Figure 8. The response of HMs to TRH changes during postnatal development. $A$, The response of an HM was classified as typical if TRH caused a decrease in $G_{N}$ to less than $85 \%$ of control; otherwise the response was considered atypical. HMs were grouped by age, and the percentage of cells that responded in a typical manner was plotted ( $n$ for each group is given in parentheses). For reference, previously reported data from adult HMs are also plotted (Bayliss et al., 1992a). There is a clear increase in the number of HMs that respond in a manner typical of adults. Inset, The averaged $G_{N}$ in TRH (percentage of control, \pm SEM) for the groups of HMs. The dashed line represents the arbitrary point used to characterize the response of a cell to TRH as typical or atypical. The percentage decrease in $G_{\mathrm{N}}$ did not change as a function of age in either the typical (solid bars) or atypical (open bars) groups. $G_{N}$ decreased to $67.2 \pm 1.9 \%$ and $97.3 \pm 1.4 \%$ of control in typical and atypical groups, respectively. The effect of TRH on $G_{N}$ in typical-responding neonatal HMs was not significantly different from adult HMs, in which $G_{N}$ decreased to $64.6 \pm 3.2 \%(n=15$; see inset and Bayliss et al., 1992a). $B$, The TRH current (1.0 $\mu \mathrm{M}$; absolute value) measured in HMs that responded in a typical manner was normalized either to cell capacitance $\left(I_{\mathrm{TRH}} / C_{M}\right.$, current density; solid bars) or to resting input conductance $\left(I_{\mathrm{TRH}} / G_{\mathrm{rssl}}\right.$, hatched bars), averaged, and plotted for each age group (mean $\pm \mathrm{SEM}$ ). Current density increased significantly as a function of age $\left(F_{4.19}=4.2, P<0.05\right)$; pairwise comparison between groups revealed that $I_{\mathrm{TRH}} / C_{M}$ was significantly higher only in the P20P21 age group $(P<0.05$, asterisk). There were no age-related differences in $I_{\mathrm{TRH}} / G_{\mathrm{rest}}\left(F_{4.19}=0.39\right)$. Note that the units for $I_{\mathrm{TRH}} / G_{\text {rest }}$ (i.e., $\left.\mathrm{nA} / \mu \mathrm{S}\right)$ are actually equivalent to millivolts, illustrating the point that the depolarizing effect of TRH in HMs that responded in a typical manner was essentially independent of age.

$7 A$, some cells showed essentially no depolarizing response to TRH (Fig. $7 A$, left) and TRH was without effect on $G_{N}$ in those cells (Fig. $7 A$, right). In other neonatal HMs (Fig. $7 B I$ ), $\mathrm{IRH}$ caused a slight depolarization that was associated with a sub- stantial increase in synaptic activity, but that was apparently independent of changes in $G_{N}$. The depolarizing effect of TRH in this cell was indirect (i.e., synaptically mediated) as the response was completely blocked in a nominally calcium-free Rin-

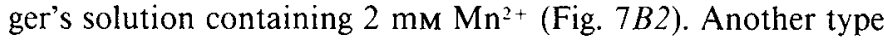
of response observed in neonatal HMs is shown in Figure $7 \mathrm{Cl}$. TRH caused a depolarization of this HM and again the depolarizing response was not associated with a change in $G_{N}$. Note, however, that the effect of TRH on this cell was direct as it was unaffected by TTX, despite the fact that TTX clearly decreased both basal and TRH-induced levels of synaptic activity. A direct effect similar to this was verified in another cell tested in $2 \mathrm{~mm}$ $\mathrm{Mn}^{2+}$, zero $\mathrm{Ca}^{2+}$. The three types of responses to TRH depicted in Figure 7 were characterized by little or no change in $G_{N}$, and were unlike (atypical of) those recorded in any adult HMs.

We defined a response as typical (i.e., adult-like) if TRH caused a decrease in $G_{N}$ to less than $85 \%$ of control (Fig. 6); otherwise the response was considered atypical (Fig. 7). Figure $8 A$ (inset) shows the averaged effect of TRH on $G_{N}$ (percentage of control) in HMs that responded in a manner deemed atypical (open bars) or typical (solid bars) at different postnatal ages. The mean TRHinduced decrease in $G_{N}$ for all typical-responding neonatal HMs was similar to that reported previously for adult HMs (67.2 \pm $1.9 \%$ and $64.6 \pm 3.2 \%$ of control, respectively; Bayliss et al., 1992a) but was different from that found in neonatal cells that responded in an atypical manner $(97.3 \pm 1.4 \%$ of control). The percentage decrease in $G_{N}$ did not change as a function of age in either group $\left(F_{3,25}=1.9\right)$. In all cases tested $(n=5)$, a cell that displayed an atypical response to $1 \mu \mathrm{M}$ TRH also did so when challenged with $10 \mu \mathrm{M} \mathrm{TRH}$, ruling out the possibility that an insufficient dose of TRH accounted for this response type. The percentage of cells responding in a manner typical of adult HMs at different postnatal ages is shown in Figure 8.4 . It is clear that there is a progressive increase with age in the percentage of cells that showed an "adult-like" response. There were no differences between these groups (typical and atypical) in $E_{M}\left(F_{1.36}=0.22\right)$ or spike threshold $\left(F_{1.34}=0.01\right)$ or, after controlling for age, in $G_{N}\left(F_{1,25}=0.61\right)$ or $\tau_{M}\left(F_{1,24}=3.2\right)$. Because these groups were similar in all variables measured, except in their response to TRH, it is unlikcly that atypical responses were due to mistakes in neuronal identification.

We determined the magnitude of $I_{\mathrm{TRH}}$ and calculated the TRH current density $\left(I_{\mathrm{TRH}} / C_{\mathrm{M}}\right)$ during application of $1 \mu \mathrm{M} \mathrm{TRH}$ for HMs that responded in a typical fashion (see Table 1, Fig. 8B). We excluded those cells that responded in an atypical manner from this analysis because apparently different mechanisms mediated the response of those cells to TRH. Holding potential $\left(V_{\text {hold }}\right.$ ) for TRH application in typical-responding cells was -65.6 $\pm 0.9 \mathrm{mV}$ and was not different among the age groups. Both $I_{\text {TRH }}$ (Table 1) and $I_{\text {TRH }} / C_{M}$ (Fig. $8 B$, solid bars) increased with postnatal age; pairwise comparison revealed that both $I_{\mathrm{TRH}}$ and $I_{\mathrm{TRH}} / C_{M}$ were significantly higher in the $\mathrm{P} 20-\mathrm{P} 21$ group than in the other groups, in which they were not different. As indicated earlier, resting $G_{N}$ increases dramatically in HMs during the early postnatal period (Table 1; compare P0 and P16 HMs in Fig. 6). It is therefore noteworthy, as shown in Figure $8 B$ (hatched bars), that TRH current normalized to resting conductance $\left(I_{\mathrm{rRH}} / G_{\text {rest }}\right)$ was independent of age in those cells that responded in a typical fashion; that is, TRH current increased proportionally with increases in resting $G_{N}$ such that the ratio of the two remained unchanged. This implies that the TRH-sensitive conductance underlying the TRH current also increased in proportion to 
Table 1. Membrane properties and TRH current amplitude in HMs that responded in a typical fashion

\begin{tabular}{lccccc} 
& P0-P2 & P3-P5 & P6-P8 & P11-P16 & P20-P21 \\
\hline$V_{\text {hold }}(\mathrm{mV})^{a}$ & $-61.0 \pm 3.0(2)$ & $-65.0 \pm 6.0(2)$ & $-65.0 \pm 1.9(4)$ & $-68.3 \pm 1.7(7)$ & $-64.9 \pm 1.2(9)$ \\
$G_{\text {rest }}(\mu \mathrm{S})$ & $0.020 \pm 0.006(2)$ & $0.024 \pm 0.003(5)$ & $0.029 \pm 0.004(5)$ & $0.049 \pm 0.009(7)$ & $0.102 \pm 0.011(9)^{*}$ \\
$\tau_{M}(\mathrm{msec})$ & $11.3 \pm 0.0(2)^{+} \dagger$ & $8.3 \pm 1.2(5) \dagger$ & $8.4 \pm 1.4(4) \dagger$ & $5.9 \pm 1.7(7) \dagger$ & $2.9 \pm 0.4(9)$ \\
$C_{1 /}(\mathrm{nF})$ & $0.22 \pm 0.07(2)$ & $0.19 \pm 0.03(5)$ & $0.22 \pm 0.02(4)$ & $0.21 \pm 0.02(7)$ & $0.29 \pm 0.05(9)$ \\
$I_{\text {TRH }}(\mathrm{nA})^{a}$ & $-0.26 \pm 0.08(2)$ & $-0.35 \pm 0.19(2)$ & $-0.28 \pm 0.09(4)$ & $-0.54 \pm 0.11(7)$ & $-1.3 \pm 0.16(9)^{*}$
\end{tabular}

Data are presented as means \pm SEM (number of cells). In this group of HMs, there were no age-related differences in $V_{\text {hold }}\left(F_{4.19}=1.3\right)$ or $C_{1:}\left(F_{4,22}=1.0\right)$; there were significant age effects on $G_{\text {rest }}\left(F_{+.23}=13.7, p<0.0001\right), \tau_{M}\left(F_{4.22}=5.8, p<0.005\right)$, and $I_{\mathrm{TRH}}\left(F_{4.99}=8.9, p<0.0005\right)$. ${ }^{*}$, significantlly different fruml all ullier gruups; + , significantly greater than P11-P16; $\dagger$, significantly greater than P20-P21 $(p<0.05)$.

"Only includes data from HMs tested with $1.0 \mu \mathrm{M}$ TRH.

increases in $G_{\text {rest }}$. Consistent with this, the percentage of $G_{\text {rest }}$ inhibited by $1 \mu \mathrm{M}$ TRH (i.e., the TRH-sensitive conductance) was similar $(\sim 30-35 \%)$ in typical-responding cells at all ages (Fig. $8 A$, inset; $F_{4,20}=2.19$ ).

It is clear that the manner in which HMs respond to $\mathrm{TRH}$ (i.e., typical or atypical) and the magnitude of the response (i.e., $I_{\mathrm{TRH}}$ or $I_{\mathrm{TRH}} / C_{M}$ ) develop over the carly postnatal period. The age-dependent increase in TRH current density in typical-responding cells was proportional to increases in $G_{\text {rest }}$ over the same time period. It is important to note, however, that even at the youngest time point studied ( $<1 \mathrm{hr}$ old; Fig. 6) a small percentage of HMs responded in a manner essentially indistinguishable from adults.

\section{Discussion}

The results of this study indicate that major developmentrelated changes occur in the TRH neuronal system of the rat brainstem during the first $2-3$ weeks following birth. In caudal raphe nuclei, we found that TRH mRNA increased from barely detectable levels at birth to high levels by P14 and we showed that the TRH innervation of $\mathrm{nXII}$, which is derived from the caudal raphe (Lynn et al., 1991), increased within a similar time framc. In addition, we demonstrated a substantial increasc in TRH binding in nXII over the first 2 postnatal weeks. Finally, electrophysiological effects of TRH on HMs changed during this period; we found an increase in the percentage of cells that respond to TRH in a manner typical of adult motoneurons (i.e., depolarization with decreased $G_{N}$; Rekling, 1990; Bayliss et al., 1992a) and showed that the TRH current density also increased. Thus, we have combined a number of approaches to provide a reasonably complete description of the postnatal development of this important peptidergic neuronal system in rat brainstem.

Our in situ hybridization and immunohistochemical studies indicate that TRH expression in the caudal brainstem increases during the early postnatal period. These findings are supported by previous radioimmunoassay experiments in which TRH levels in rat brainstem extracts were undetectable (Lamberton et al., 1984) or at low levels (Jeffcoate et al., 1983) before birth and increased postnatally to near adult levels by P20-P28 (Jeffcoate et al., 1983; Lamberton et al., 1984). The developmental pattern of TRH mRNA expression that we have described in brainstem raphe nuclei is remarkably similar to that in the rat thalamic reticular nucleus where TRH mRNA is first detected at P7 and increases thereafter to peak by around P21 (Burgunder and Taylor, 1989). Although hypothalamic neurons begin to express TRH prenatally rather than postnatally, they are similar to raphe and thalamic reticular neurons in that their expression of TRH mRNA increases over approximately a 2-3 week period (Burgunder and Taylor, 1989). Thus, a common finding among TRH-synthesizing cells is that, following the initial expression of TRH, a 2-3 week period of time is necessary for TRH mRNA to reach adult levels.

We found that the number of TRH-IR fibers in $\mathrm{X}$ XII increased during the carly postnatal period from low levels at $\mathrm{PO}$ to near adult levels by $\mathrm{P} 21$. These findings are comparable to those of a recent study of pre- and postnatal development of TRH-IR fibers in the spinal cord ventral horn in which a substantial increase in TRH innervation was reported from P0 to P2 1 (Poulat et al., 1992). In the present work we did not examine the TRH innervation of $n$ XII during the prenatal period. Poulat et al. (1992) detected some TRH-IR fibers in the spinal cord prenatally (first detected at embryonic day 17 ) as well as at P0, but the density was extremely low. These fibers, like those in nXII, are derived from ROb and RPa (Johansson et al., 1981), implying that some raphe neurons synthesize $\mathrm{TRH}$ by $\mathrm{P} 0$. In fact, we demonstrated that TRH mRNA was expressed at low levels in some raphe neurons at $\mathrm{P0}$ (see Fig. $2 A$ ).

The postnatal increase of TRH innervation in $\mathrm{nXII}$ that we report could result from the arrival of new TRH-containing fibers or from the late appearance of TRH in fibers that were already present in $\mathrm{nXII}$. The former possibility is unlikely because TRH is extensively colocalized with 5-HT in fibers in the adult (Johansson et al., 1981) and a substantial 5-HT innervation of nXII is already present at the time of birth (D. E. Millhorn, unpublished observations). Furthermore, a recent study on postnatal development of the SP raphe neuronal system reported findings strikingly similar to those we have described for TRH; increased numbers of SP-IR raphe neurons and SPIR fibers around spinal motoneurons were found from $\mathrm{PO}$ through P28 (Ozaki et al., 1992). Importantly, the coexistent ratio of 5-HT and SP in raphe neurons and in single fibers increased, with little change in the total number of 5-HT fibers, suggesting that the increase in SP-IR in fibers around spinal motoneurons is due to belated appearance of SP in preexisting 5-HT fibers (Ozaki et al., 1992). A similar belated appearance of TRH in 5-HT-containing fibers could account for our immunohistochemical results.

We found the amount of ${ }^{3} \mathrm{H}-\mathrm{MeTRH}$ binding increased postnatally in $\mathrm{NXII}$. Developmental increases in the density of TRH binding sites have also been reported in other CNS structures (e.g., hypothalamus, striatum, amygdala) (Blanchard and Barden, 1986). In contrast, TRH binding reportedly decreased from approximately 2 weeks of age to adulthood in spinal cord membranes (Prasad, 1989). A direct comparison of those earlier re- 
sults from ${ }^{3} \mathrm{H}$-MeTRH binding to spinal cord membranes with data presented here is difficult; the earlier report included tissue from outside motor nuclei and was restricted to time points after P11. Although we did not specifically address mechanisms that might mediate the increase in TRH binding, it is worth noting that in other cases where increases in TRH binding have been demonstrated changes were due solely to increased number of binding sites $\left(B_{\max }\right)$ and were independent of changes in binding affinity $\left(K_{d}\right)$ (Blanchard and Barden, 1986; reviewed in Sharif, 1989).

Developmental changes in electrophysiological responses of HMs to TRH paralleled changes in ${ }^{3} \mathrm{H}-\mathrm{MeTRH}$ binding in $\mathrm{nXII}$, and thus may reflect increased TRH receptor expression. For example, we found very high levels of TRH binding in nXII of neonate rats by $\mathrm{P} 14$ and every HM older than P11 responded in a manner typical of adults. Conversely, at times when there was little TRH binding in $\mathrm{nXII}(\leq \mathrm{P} 7)$ we found that a number of neonatal HMs did not respond to TRH. This finding is especially significant given the earlier demonstration that all adult HMs responded to TRH (Rekling, 1990; Bayliss et al., 1992a). In an earlier study, Wang and Dun (1990) reported that many $(48 \%)$ neonatal spinal motoneurons did not respond directly to TRH, although TRH did increase synaptic activity in many of those nonresponsive cells. There is no information at present regarding the percentage of adult spinal motoneurons that respond to TRH. It is interesting that, after P11, we found that all HMs responded in a typical fashion, while apparently half of the older spinal motoneurons (P12-P16) sampled by Wang and Dun (1990) still responded in a manner we would classify as atypical. Perhaps HMs, which innervate tongue muscles and control behaviors critical to survival of the neonate (e.g., suckling, airway patency), though not fully mature, are developmentally advanced relative to spinal motoneurons at the time of birth.

Mechanisms in addition to TRH receptor expression may influence the manner (typical vs atypical) in which neonatal HMs respond to TRH. In adult HMs, two components of the TRII-induced depolarization could be discriminated by their sensitivity to barium; $I_{\mathrm{TRH}}$ resulted (1) from inhibition of a barium- and TRH-sensitive resting $\mathrm{K}^{+}$conductance (accounting for the effect of TRH on $G_{N}$ ), and (2) from induction of a bariuminsensitive inward current that was apparently independent of changes in $G_{N}$ (Bayliss et al., 1992a). Interestingly, a direct effect of TRH in some neonatal HMs was a depolarization independent of a measurable change in $G_{N}$ (see Fig. $7 C$ ). This was reminiscent of the second component of $I_{\mathrm{TRH}}$ observed in adult HMs, but only after inhibition by barium of the TRH-sensitive resting $\mathrm{K}^{+}$conductance. Because this atypical effect of TRH was direct, neonatal HMs that responded in this manner were presumably endowed with TRH receptor. It is possible that TRH was without effect on $G_{N}$ in these neonatal HMs because they did not possess the TRH-sensitive resting $\mathrm{K}^{+}$conductance. However, this is not entirely consistent with other data that indicated $G_{\text {rest }}$ was not different in typical and atypical groups even though the TRH-sensitive resting $\mathrm{K}^{+}$conductance usually accounts for $\sim 30-35 \%$ of $G_{\text {rest }}$. An alternative possibility is that intracellular mechanisms coupling the TRH receptor to the barium-insensitive component of $I_{\mathrm{TRH}}$ were functional in some atypical-responding neonatal HMs, whereas those coupling the receptor to the $\mathrm{TRH}$-sensitive $\mathrm{K}^{+}$conductance were not. Test of this latter possibility awaits elucidation of the intracellular mechanisms mediating the response to TRH in HMs.
We have described a developmental increase in TRH current density among typical-responding HMs that may reflect an increase in the density of the TRH-sensitive $\mathrm{K}^{+}$channels. Consistent with this, the relative contribution of the TRH-sensitive conductance to $G_{\text {rcsi }}$ in typical-responding HMs remained constant at $\sim 30-35 \%$ even though $G_{\text {rest }}$ increased substantially with age. Moreover, the inward current induced in HMs at rest by barium, which acts predominantly by decreasing the TRH-sensitive $\mathrm{K}^{+}$conductance (Bayliss et al., 1992a), is greater in adult than in neonatal HMs (approximately three- to fourfold increase from P8-P11 to >P21; Bayliss and Viana, unpublished observations). The increase in TRH-sensitive current is functionally very important as it allows TRH to cause a significant depolarization in older HMs despite their higher $G_{\text {resi }}$. In fact, the increase in TRH current occurred in direct proportion to increases in $G_{\text {ress }}$, such that the magnitude of the depolarizing response in older and younger typical-responding HMs was essentially identical (see Fig. 6 and Fig. $8 B$, hatched bars).

It is important to note that even at the earliest time point studied, when there was little TRH expression in raphe neurons and few TRH-IR fibers in $\mathrm{nXII}$, it was possible to find some neonatal HMs that responded to exogenously applied TRH in a manner qualitatively identical to adult HMs. Apparently, some HMs anticipated the arrival of the endogenous TRH innervation. On the whole, however, increases in the percentage of typical electrophysiological responses and TRH binding in $\mathrm{NXII}$ closely paralleled increases in TRH expression in raphe cells and TRH innervation of $\mathrm{nXII}$, suggesting tightly coordinated regulation of transmitter and receptor. The mechanism for this coordinated regulation has yet to be determined. It is possible that HMs provide a signal that acts retrogradely to stimulate synthesis of TRH in ROb and RPa. Conversely, an anterograde factor elaborated by the TRH-containing fibers, perhaps TRH itself, may stimulate $H M$ s to synthesize TRH receptors. This latter possibility is unlikely because chemotoxic lesions of raphe neurons in the neonate lead to an increase (Sharif et al., 1989), and pretreatment with TRH or its analogs leads to a decrease, in TRH binding sites (reviewed in Sharif, 1989), suggesting that under normal circumstances raphe neurons and/or TRH actually inhibit the synthesis of TRH receptors. An alternative possibility is that independent developmental genetic programs are followed in which expression of TRH in raphe cells and TRH receptor in HMs are extremely well timed, one with the other. It may ultimately be found that some combination of these three types of mechanisms (retrograde, anterograde, and genetic) interact to determine the phenotype in raphe neurons and HMs.

\section{References}

Aghajanian GK, Rasmussen K (1989) Intracellular studies in the facial nucleus illustrating a simple new method for obtaining viable motoneurons in adult rat brain slices. Synapse 3:331-338.

Aldes LD, Chronister RC, Marco LA, Haycock JW, Thibault J (1988) Differential distribution of biogenic amines in the hypoglossal nucleus of the rat. Exp Brain Res 73:305-314.

Bayliss DA, Wang Y-M, Zahnow CA, Joseph DR, Millhorn DE (1990) Localization of histidine decarboxylase mRNA in rat brain. Mol Cell Ncurosci 1:3-9.

Bayliss DA, Viana F, Berger AJ (1992a) Mechanisms underlying excitatory effects of thyrotropin-releasing hormone on rat hypoglossal motoneurons in vitro. J Neurophysiol 68:1733-1745.

Bayliss DA, Viana F, Berger AJ (1992b) Early postnatal changes in rat hypoglossal motoneuron responses to thyrotropin-releasing hormone (TRH) and serotonin (5-HT) in vitro. Soc Neurosci Abstr 18: 511 . 
Bayliss DA, Viana F, Bellingham MC, Berger AJ (in press) Characteristics and postnatal development of a hyperpolarization-activated inward current $\left(I_{h}\right)$ in rat hypoglossal motoneurons in vitro. J Neurophysiol, in press.

Blanchard L, Barden N (1986) Ontogeny of receptors for thyrotropinreleasing hormone in the rat brain. Brain Res 389:85-88.

Brown MC, Jansen JKS, Van Essen D (1976) Polyneuronal innervation of skeletal muscle in new-born rats and its elimination during maturation. J Physiol (Lond) 261:387-422.

Burgunder J-M, Taylor T (1989) Ontogeny of thyrotropin-releasing hormone gene expression in the rat diencephalon. Neuroendocrinology 49:631-640.

Burt DR, Sharif NA (1990) TRH receptors. In: Handbook of chemical neuroanatomy, Vol 9 (Bjorklund A, Hökfelt T, Kuhar MJ, eds), pp 477-503. Amsterdam: Elsevier.

Calzá L, Giardino L, Ceccatelli S, Zanni M, Elde R, Hökfelt T (1992) Distribution of thyrotropin-releasing hormone messenger RNA in the rat brain: an in situ hybridization study. Neuroscience 51:891-909.

Coons AH (1958) Fluorescent antibody methods. In: General cytochemical methods (Danielli JF, ed), pp 399-422. New York: Academic.

Finkel AS, Redman SJ (1985) Optimal voltage clamping with single microelectrodes. In: Voltage and patch clamping with microelectrodes (Smith TG Jr, Lecar H, Redman SJ, Gage PW, eds), pp 95-120. Bethesda, MD: American Physiological Society.

Fulton BP, Walton K (1986) Electrophysiological properties of neonatal rat motoneurones studied in vitro. J Physiol (Lond) 370:651678.

Haddad GG, Donnelly DF, Getting PA (1990) Biophysical properties of hypoglossal neurons in vitro: intracellular studies in adult and neonatal rats. J Appl Physiol 69:1509-1517.

Hökfelt T, Fuxe K, Johansson O, Jeffcoate S, White N (1975a) Distribution of thyrotropin-releasing hormone (TRH) in the central nervous system as revealed by immunohistochemistry. Eur J Pharmacol 34:389-392.

Hökfelt T, Fuxe K, Johansson O, Jeffcoate S, White N (1975b) Thyrotropin releasing hormone (TRH)-containing nerve terminals in certain brain stem nuclei and in the spinal cord. Neurosci Lett 1:133139

Jacobs BL, Azmitia EC (1992) Structure and function of the brain serotonin system. Physiol Rev 72:165-229.

Jeffcoate SL, Linton EA, Lira O, White N (1983) Age-dependent changes in the brain content, enzymic inactivation, and hypophysiotropic action of TRH in the rat. In: Thyrotropin-releasing hormone (Griffiths EC, Bennett GW, eds), pp 145-155. New York: Raven.

Johansson O, Hökfelt T, Pernow B, Jeffcoate SL, White N, Steinbusch HWM, Verhofstad AAJ, Emson PC, Spindel E (1981) Immunohistochemical support for three putative transmitters in one neuron: coexistence of 5-hydroxytryptamine, substance P- and thyrotropin releasing hormone-like immunoreactivity in medullary neurons projecting to the spinal cord. Neuroscience 6:1857-1881.

Lamberton RP, Lechan RM, Jackson IMD (1984) Ontogeny of thyrotropin-releasing hormone and histidyl proline diketopiperazine in the rat central nervous system and pancreas. Endocrinology 1 15:24002405 .

Lechan RM, Wu P, Jackson IMD, Wolf H, Cooperman S, Mandel G, Goodman RH (1986) Thyrotropin-releasing hormone precursor: characterization in rat brain. Science 231:159-161.

Lynn RB, Kreider MS, Miselis RR (1991) Thyrotropin-releasing hormone-immunoreactive projections to the dorsal motor nucleus and the nucleus of the solitary tract of the rat. J Comp Neurol 311:271288

Manaker S, Rizio G (1989) Autoradiographic localization of thyrotropin-releasing hormone and substance $\mathbf{P}$ receptors in the rat dorsal vagal complex. J Comp Neurol 290:516-526.

Merchenthaler I, Csernus V, Csontos C, Petrusz P, Mess B (1988) New data on the immunocytochemical localization of thyrotropin-releasing hormone in the rat central nervous system. Am J Anat 181:359376.

Millhorn DE, Szymeczek CL, Bayliss DA, Seroogy KB, Hökfelt T (1991) Cellular, molecular and developmental aspects of chemical synaptic transmission. In: Developmental neurobiology of breathing (Haddad GG, Farber JP, eds), pp 11-70. New York: Dekker.
Navarette R, Vrbová G (1983) Changes of activity patterns in slow and fast muscles during postnatal development. Dev Brain Res 8:1119.

Nistri A, Fisher ND, Gurnell M (1990) Block by the neuropeptide TRH of an apparently novel $\mathrm{K}^{+}$conductance of rat motoneurons. Neurosci Lett 120:25-30.

Ozaki S, Kudo N, Okado N (1992) Immunohistochemical study on development of serotonin-, substance $\mathrm{P}_{-}$, and enkephalin-positive fibers in the rat spinal motor nucleus. J Comp Neurol 325:462-470.

Paxinos G, Watson C (1986) The rat brain in stereotaxic coordinates. Orlando: Academic.

Poulat P, Legrand A, Rajaofetra N, Marlier L, Privat A, Oliver C (1992) Pre- and post-natal ontogeny of thyrotropin-releasing hormone in the rat spinal cord: an immunocytochemical study. Dev Brain Res 70: $245-2.57$

Prasad C (1989) Postnatal development of the spinal cord thyrotropinreleasing hormone receptor in male and female rats. Neurosci Lett 102:253-256.

Rajaofetra N, Sandillon F, Geffard M, Privat A (1989) Pre- and postnatal ontogeny of serotonergic projections to the rat spinal cord. J Neurosci Res 22:305-321.

Rekling JC (1990) Excitatory effects of thyrotropin-releasing hormone (TRH) in hypoglossal motoneurons. Brain Res 510:175-179.

Remmers JE, DeGroot WJ, Sauerland EK, Anch AM (1978) Pathogenesis of upper airway occlusion during sleep. J Appl Physiol Respir Environ Exercise Physiol 44:931-938.

Sah P, McLachlan EM (1992) Potassium currents contributing to action potential repolarization and the afterhyperpolarization in rat vagal motoneurons. J Neurophysiol 68:1834-1841.

Segerson TP, Hoefler H, Childers H, Wolfe HJ, Wu P, Jackson IMD, Lechan RM (1987) Localization of thyrotropin-releasing hormone prohormone messenger ribonucleic acid in rat brain by in situ hybridization. Endocrinology 121:98-107.

Seroogy KB, Bayliss DA, Szymeczek CL, Hökfelt T, Millhorn DE (1991) Transient expression of somatostatin messenger RNA and peptide in the hypoglossal nucleus of the neonatal rat. Dev Brain Res 60:241252.

Sharif NA (1989) Quantitative autoradiography of TRH receptors in discrete brain regions of different mammalian species. Ann NY Acad Sci 53:147-175.

Sharif NA, Towle AC, Burt DR, Mueller RA, Breese GR (1989) Cotransmitters: differential effects of serotonin (5-HT)-depleting drugs on levels of 5-HT and TRH and their receptors in rat brain and spinal cord. Brain Res 480:365-371.

Szymeczek CL, Erickson JT, Bayliss DA, Millhorn DE (1990) Developmental changes in thyrotropin releasing hormone mRNA levels in rat raphe medullary neurons. FASEB J 4:A1109.

Takahashi T (1985) Thyrotropin-releasing hormone mimics descending slow synaptic potentials in rat spinal motoneurons. Proc $\mathrm{R}$ Soc Lond [Biol] 225:391-398.

Tsuruo Y, Hökfelt T, Visser T (1987) Thyrotropin-releasing hormone (TRH)-immunoreactive cell groups in the rat central nervous system. Exp Brain Res 68:213-217.

Viana F, Gibbs L, Berger AJ (1990) Double- and triple-labeling of functionally characterized central neurons projecting to peripheral targets studied in vitro. Neuroscience 38:829-841.

Viana F, Bayliss DA, Berger AJ (in press) Postnatal changes in rat hypoglossal motoneuron membrane properties. Neuroscience, in press.

Wallenstein S, Zucker CL, Fleiss JL (1980) Some statistical methods useful in circulation research. Circ Res 47:1-9.

Wang MY, Dun NJ (1990) Direct and indirect actions of thyrotropinreleasing hormone on neonatal rat motoneurons in vitro. Neurosci Lett 113:349-354.

Willinger M (1989) SIDS: a challenge. J NIH Res 1:73-80.

Yarom Y, Sugimori M, Llinas R (1985) Ionic currents and firing patterns of mammalian vagal motoneurons in vitro. Neuroscience 16: 719-737.

Zamboni L, DeMartino C (1967) Buffered picric acid formaldehyde: a new rapid fixative for electron microscopy. J Ceil Biol 35:148A.

Ziskind-Conhaim L, Seebach BS, Gao B-X (1993) Changes in serotonin-induced potentials during spinal cord development. J Neurophysiol 69:1338-1349. 